Article

\title{
A Comparative Study on the Faecal Bacterial Community and Potential Zoonotic Bacteria of Muskoxen (Ovibos moschatus) in Northeast Greenland, Northwest Greenland and Norway
}

\author{
Emilie U. Andersen-Ranberg 1,2,*iD , Christopher J. Barnes ${ }^{3}$ iD , Linett Rasmussen ${ }^{3}$, \\ Alejandro Salgado-Flores ${ }^{4}$, Carsten Grøndahl ${ }^{5}$, Jesper B. Mosbacher ${ }^{1,+}$, Anders J. Hansen ${ }^{3}$, \\ Monica Alterskjær Sundset ${ }^{4}$, Niels Martin Schmidt ${ }^{1}$ (D) and Christian Sonne ${ }^{1}$ (i) \\ 1 Department of Bioscience, Faculty of Science and Technology, Arctic Research Centre, Aarhus University, \\ 4000 Roskilde, Denmark; jemo@bios.au.sk (J.B.M.); nms@bios.au.dk (N.M.S.); cs@bios.au.dk (C.S.) \\ 2 Department of Veterinary Clinical and Animal Sciences, Faculty of Health and Medical Sciences, \\ University of Copenhagen, 1870 Frederiksberg, Denmark \\ 3 Centre for GeoGenetics, Natural History Museum of Denmark, University of Copenhagen, 1350 \\ Copenhagen, Denmark; c.barnes@snm.ku.dk (C.J.B.); linett.rasmussen@snm.ku.dk (L.R.); \\ ajhansen@snm.ku.dk (A.J.H.) \\ 4 Department of Arctic and Marine Biology, UiT-The Arctic University of Norway, 9037 Tromsø, Norway; \\ alejandro.f.salgado@uit.no (A.S.-F.); monica.a.sundset@uit.no (M.A.S.) \\ 5 Copenhagen Zoo, Centre for Zoo and Wild Animal Health, DK-2000 Frederiksberg, Denmark; cg@zoo.dk \\ * Correspondence: emilie.ranberg@sund.ku.dk; Tel.: +45-2216-5459 \\ + Current address: Department of Ecosystem and Public Health, Faculty of Veterinary Medicine, \\ University of Calgary, Calgary, AB T2N 4Z6, Canada.
}

Received: 31 May 2018; Accepted: 19 July 2018; Published: 25 July 2018

\begin{abstract}
Muskoxen (Ovibos moschatus) are ruminants adapted to a high-fibre diet. There is increasing interest in the role that gut microbes play in the digestion and utilization of these specialized diets but only limited data available on the gut microbiome of high-Arctic animals. In this study, we metabarcoded the 16S rRNA region of faecal samples from muskoxen of Northeast Greenland, Northwest Greenland and Norway, and quantified the effects of physiological and temporal factors on bacterial composition. We found significant effects of body mass, year of sampling and location on the gut bacterial communities of North East Greenland muskoxen. These effects were however dwarfed by the effects of location, emphasizing the importance of the local ecology on the gut bacterial community. Habitat alterations and rising temperatures may therefore have a considerable impact on muskoxen health and reproductive success. Moreover, muskoxen are hunted and consumed in Greenland, Canada and Alaska; therefore, this study also screened for potential zoonoses of food safety interest. A total of 13 potentially zoonotic genera were identified, including the genera Erysipelothrix and Yersinia implicated in recent mass die-offs of the muskoxen themselves.
\end{abstract}

Keywords: Ovibos moschatus; muskoxen; Arctic; zoonoses; 16S rRNA; metabarcoding; faecal bacterial community

\section{Introduction}

Only a few large terrestrial mammals have adapted to life in the high Arctic. The muskox (Ovibos moschatus) is the largest (150-300 kg) of only a handful of ruminants to do so and they roam areas of northern Canada, Northeast Greenland and Alaska. They have been further introduced to Norway, West Greenland, Wrangel Island and the Taimyr Peninsula [1]. Approximately 90,000 animals are 
estimated to exist in the wild in Alaska, Canada and Greenland but numbers are declining in Canada and Northeast Greenland [1,2]. Muskoxen mainly forage on graminoids and shrubs [3-5]. High Arctic summers are short and provide the muskoxen with energy rich pastures for a limited time [6]; the winter is long and offers limited forage that is high in fibres (lignocellulosic macromolecules) [5,7].

These fibres are the main source of energy for ruminants [8] and the degradation of fibre is mediated by (i) symbiotic anaerobic microbes producing short chain fatty acids, an essential source of energy for ruminants and (ii) long retention time in the rumen and hindgut providing enough time for efficient microbial fermentation $[9,10]$. Microbes present different abilities to ferment and process carbohydrates and perhaps unsurprisingly, diet is a key factor influencing the gut microbiota [11-14]. High Arctic muskoxen have evolved the specialized ability to utilize a diet rich in highly complex carbohydrates to survive the extreme conditions of the long winter of the high Arctic $[15,16]$ and their digestive bacterial community plays an essential role in their survival [8]. Qi et al. [15] correspondingly found a high proportion of cellulolytic enzymes in the rumen of muskoxen. Though ruminal microbiomes have been extensively investigated [17], the sampling technique involved is not readily applicable to wild animals, unless post mortem. Faecal sampling on the other hand, represents a non-invasive and potentially low-stress procedure for sampling wild animals; and while a majority of the digestion is believed to occur in the rumen, it continues through the length of the intestinal tract including the hindgut.

The composition and regulation of muskoxen gut microbiota remains almost entirely unknown [15,16], with effects of location and subsequent variations in feed availability and climate, that are largely undetermined. It is also unknown whether the gut bacterial community varies within populations, with factors such as age, seasonal or annual fluctuations, sex and body mass never investigated. Given the likely importance of the gut microbial community in processing a high fibre diet, understanding the regulation of muskox gut microbial communities is extremely timely in light of the rapid changes occurring in the Artic regions. In agreement with this, Davidson et al., 2011 [18] (p. 6) proposed that "comparisons between Arctic fauna and relocated satellite populations at the edge of their climatic range (e.g., muskoxen imported to Norway from Greenland during the past century) can provide early warnings for potential threats to Arctic fauna resulting from alterations in the environment, such as climate change."

Moreover, muskoxen are hunted and consumed in Northwest and West Greenland, certain areas of East Greenland as well as in Canada and Alaska. In West Greenland, by Kangerlussuaq, it is taking place as a semi-structured slaughter for commercial and herd control purposes. The potential transfer of zoonotic diseases by consumption or handling of muskoxen is a food safety and health issue that has not been investigated in a broad sense in Greenland and a desire for in depth investigations are iterated by the Inuit community as well as official bodies [19-22].

Here, we characterize the faecal bacterial composition via $16 \mathrm{~S}$ rRNA sequencing of wild Northeastand introduced Norwegian (Tromsø) muskoxen, with three main objectives: our first objective was to quantify the effects of physiological factors (sex, body mass) and temporal (year of sampling) effects on the gut bacterial composition of the Northeast Greenlandic muskoxen. The second objective was to quantify the effect of changing geographical location on the bacterial composition in muskoxen faeces, comparing populations from Norway and Northeast Greenland. The final objective was to report the occurrence of potential zoonotic bacteria present in the bacterial community of faeces (as an indicator for intestinal reservoirs for zoonoses) from muskoxen of Northeast Greenland, Norway and Northwest Greenland.

\section{Materials and Methods}

\subsection{Sampling}

In total, 35 adult wild muskoxen (29 females, six males) from the national park of Northeast Greenland (NEGM) were immobilized in September 2013 and September 2015 on the tundra at 
Zackenberg Research Station $\left(74^{\circ} 28^{\prime} \mathrm{N}, 20^{\circ} 34^{\prime} \mathrm{W}\right.$ ) (Figure 1) [23]. Faecal samples were collected directly from the rectum using nitrile laboratory gloves (TouchNTuff ${ }^{\circledR}$ Ansell Healthcare, Iselin, NJ, USA) and prior to insertion of rectal thermometer for anaesthetic monitoring. Age was determined based on horn morphology, in agreement with Olesen and Thing 1984 [24]. Body mass (kg) was determined by lifting the animal on a blanket attached to six luggage scales.

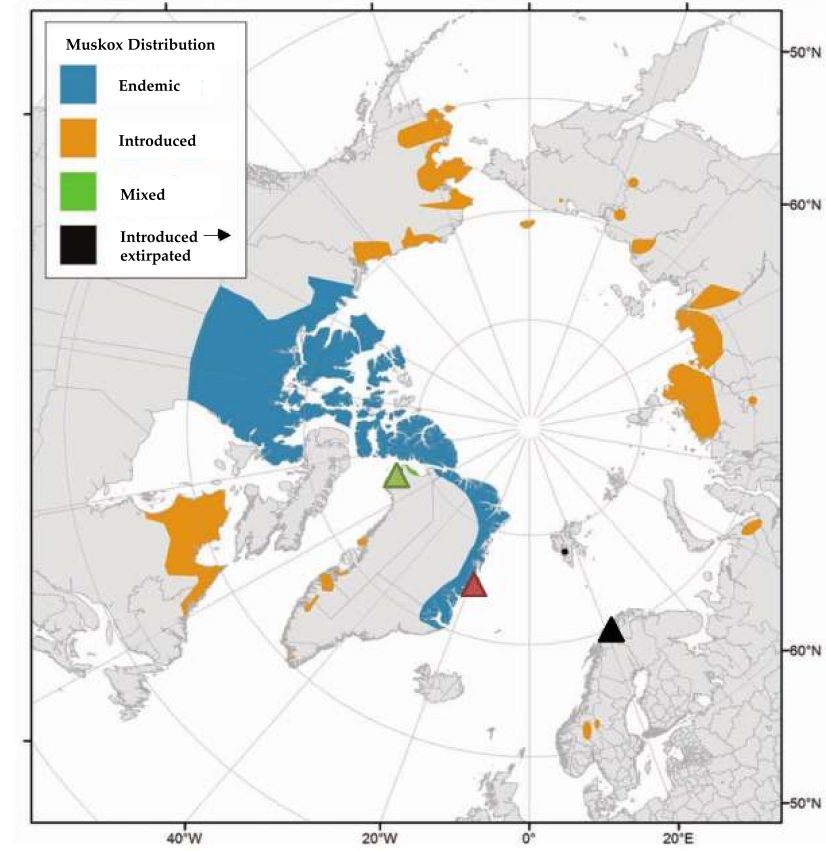

Figure 1. (a) Distribution of muskoxen worldwide and indication of sampling sites. Green triangle: Dundas Village ("NWGM," $n=4$ faecal samples), red triangle: Zackenberg Research Station ("NEGM," $n=35$ ), black triangle: Tromsø, Ryøya ("NM," $n=3$ ), modified from [1]; (b) Muskoxen by the foot of Zackenberg mountain, near Zackenberg Research Station, Photo: Lars Holst Hansen.

Faecal samples were collected from three adult Norwegian muskoxen (NM) 3 September 2010, immediately after dropping while grazing on patches of grassland and heather in open birch and pine forests, on the Island of Ryøya $\left(69^{\circ} 33^{\prime} \mathrm{N}, 18^{\circ} 43^{\prime}\right.$ E) outside Tromsø in northern Norway [16] (Figure 1). These animals belonged to UiT: the Arctic University of Norway and were kept for research purposes. This population descends from 25 muskoxen imported in 1969 from East-Greenland, King Christian X Land, in the Kaiser Franz Joseph Fjord and Moskusoksefjorden area.

Four faecal samples were collected from the ground on July 24th within Dundas Village, Thule, North-West Greenland $\left(76^{\circ} 34^{\prime} \mathrm{N}, 68^{\circ} 50^{\prime} \mathrm{V}\right.$, muskoxen from this area are abbreviated NWGM) (Figure 1). These animals were introduced in the 1980s from an East Greenland muskoxen population from Jameson Land [25]. These samples were, unlike for NEGM and NM, not collected fresh/immediately after dropping (later referred to as "semi-dry" samples in this work). Age of samples is not known but most likely few days $<3$ months, while: the faeces upon sampling were only semi-dry/still to some degree soft; predominantly dark brown (droppings turn nearly white with time in the high Arctic); they still emitted distinct faecal odour; and the herd had reached the location 3 months earlier and was gone at the time of sampling. However, it cannot be completely ruled out that the samples may originate from less than four individuals.

All samples were frozen immediately after collection and stored at $-20^{\circ} \mathrm{C}$ before further analysis. Since sampling was carried out differently for NWGM samples compared to NEGM and NM samples, only limited comparisons between the Western Greenland and other samples could be made.

Research permits were granted by the Greenlandic government (J. No. G13-029 and G15-019, in 2013 and 2015, respectively) and by the Greenlandic police (J. No 55se-50190-00153-15, in 2013). 


\subsection{Extraction and Library Construction}

The outermost surface ( $>2 \mathrm{~mm}$ ) of faecal samples was removed via sterile scalpel before $0.25 \mathrm{~g}$ of faecal samples underwent DNA extraction using a QIAamp PowerFecal DNA kit (Qiagen, Hilden, Germany) as per manufacturer's instructions. All extracted samples were diluted to $3 \mathrm{ng} / \mathrm{uL}$ to standardize between samples for further processing. Bacterial metabarcoding was performed on the V3-V4 region of the 16S rRNA region, using the 341F (5'-CCTAYGGGRBGCASCAG-3 $\left.{ }^{\prime}\right)$ and reverse 806R (5'-GGACTACNNGGGTATCTAAT-3') primers [26]. Internal tags ranging between 6 and 8 base pairs were added to primers to increase the number of samples that could be multiplexed per library. PCR reactions consisted of: $1 \mu \mathrm{L}$ of DNA template, $2.5 \mu \mathrm{L}$ of $\times 10$ buffer, $2.5 \mu \mathrm{L}$ of $25 \mathrm{mM} \mathrm{MgCl} \mathrm{M}_{2}$ and

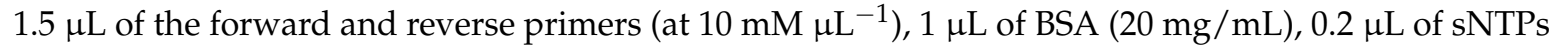
(25 mM) and $0.2 \mu \mathrm{L}$ of AmpliTaq Gold (Applied Biosystems; Thermo Fisher Scientific, Waltham, MA, USA). Cycling conditions consisted of an initial extension of $5 \mathrm{~min}$ at $95^{\circ} \mathrm{C}$, followed by 23 cycles of $95{ }^{\circ} \mathrm{C}$ for $15 \mathrm{~s}, 55^{\circ} \mathrm{C}$ for $30 \mathrm{~s}$ and $72{ }^{\circ} \mathrm{C}$ for $40 \mathrm{~s}$, with a final extension of $72{ }^{\circ} \mathrm{C}$ for 4 min also applied. DNA quality of PCR products was checked using the Qbit 2.0 fluorimeter (Thermo Fisher Scientific).

Samples were pooled for library build and purified using a QIAQUICK PCR Purification Kit (QIAGEN, Hilden, Germany). Samples were subsequently prepared for sequencing using a TruSeq DNA PCR-Free Library Preparation Kit (Illumina, San Diego, CA, USA) as per manufacturer's instructions. Libraries were checked using the 2100 Bioanalyzer (Agilent Technologies, Palo Alto, CA, USA). Final libraries underwent a purification step using AMPure XP magnetic beads in a 1:1.6 ratio of beads to library products (Beckman Coulter; Fisher Scientific, Hampton, NH, USA) and were sequenced on an Illumina MiSeq 2500 (Illumina, San Diego, CA, USA), with 250 base pair paired-end sequencing performed at the National High-Throughput Sequencing Centre of Denmark (Copenhagen, Denmark).

\subsection{Bioinformatic Analysis}

Paired ends were joined using VSEARCH (version 2.3.4) [27] and denoised, with a single base pair per read being the maximum permissible error rate. Using the internal tags, individual libraries were demultiplexed using a custom script that removes adapters, primers and the internal tags using CutAdapt (v1.9.1) [28]. Reads shorter than 400 base pairs were also excised. Reads were only assigned to samples with exact matches of both forward and reverse reads, to conservatively assign reads to samples despite tag jumping [29]. Reads were initially clustered into Operational Taxonomic Units (OTUs) based on a 97\% similarity level using the UCLUST algorithm (version 1.2.22) [30]. Chimeras were checked using the reference-based chimera checking algorithm of VSEARCH [27], while using the SILVA database [31] as a reference. Data was subsequently analysed in QIIME (v1.9.1) [32], with OTUs assigned taxonomically using the Ribosomal Database Project (RDP) classifier and the SILVA database and finally reads were deposited in the Sequence Read Archive (Bioproject: PRJNA473762). An OTU table was constructed with chimeras and singletons excluded. A total of 3,393,427 reads were left after denoising, with a minimum read length of 400 base pairs and median length 407 base pairs. Samples ranged from 10,043 and 59,992 reads per sample and were subsequently rarefied to an equal sampling depth of 10,000 reads per sample. After rarefaction, reads were assigned to a total of 3633 unique OTUs spanning 313 different genera, with $0.18 \%$ of the OTUs were completely unassigned to any taxonomic level (Spreadsheet S1).

\subsection{Statistical Analyses}

All statistical analyses were performed within $R$ (v1.0.143) [33], using the packages Vegan (v2.4.6) [34] and MVABUND (v3.13.1) [35] for analyses and ggplot (v2.2.1) [36] for data visualization.

For our first objective, the physiological and temporal factors regulating the gut bacterial community of the NEGM muskox was assessed by multivariate generalized linear modelling and analysis of variance (MGLM-ANOVA). Each OTU was treated as an explanatory variable and a 
generalized linear model (GLM) was fitted using a negative binomial distribution. Sex, body mass and year of sampling were used as explanatory variables in these models. This was performed using the manyglm, and ANOVA functions within the MVABUND package of $R$. $p$-values were calculated using 500 resampling iterations via PIT-trap resampling. In order to visualize the community data, a Bray-Curtis similarity matrix was constructed and non-metric multidimensional scaling was performed using the monoMDS function of Vegan. GLM was also performed to test the effects of body mass, sex and year of sampling on OTU richness within these East Greenland samples, also using the negative binomial distribution.

For our second objective, the effect on the microbial community by location and population was studied by comparing the microbial compositions of NEGM, NWGM and NM. As before, MGLM-ANOVA was used to test for compositional effects on the community data using location as the sole explanatory factor, however due the differences in sample collection (fresh vs. delayed/semi-dried faecal collection) the analysis was rerun without the NWGM samples. OTU richness was also investigated as before, with log-normalized OTU richness undergoing GLM to test the effect of location.

Lastly, OTUs were screened for generally accepted zoonoses. Genera were subsequently compared to a list of generally accepted zoonotic diseases described by Acha and Szyfres 2001 [37]. Acknowledging the ability for many bacteria to infect people from animal sources given the right conditions, we also compared our results to a list of bacteria associated with human infections by Paul 2012 [38].

\section{Results}

\subsection{Physiological and Temporal Effects}

For NEGM, MGLM-ANOVA identified the factors year of sampling and the animal's body mass as significantly correlated to faecal bacterial composition (Figure 2, Table 1). There was, however, no effect of the animals' sex and composition of the bacterial community. GLM revealed no significant variation in OTU richness with either year of sampling or body mass, nor did the sex of the host effect the bacterial richness.

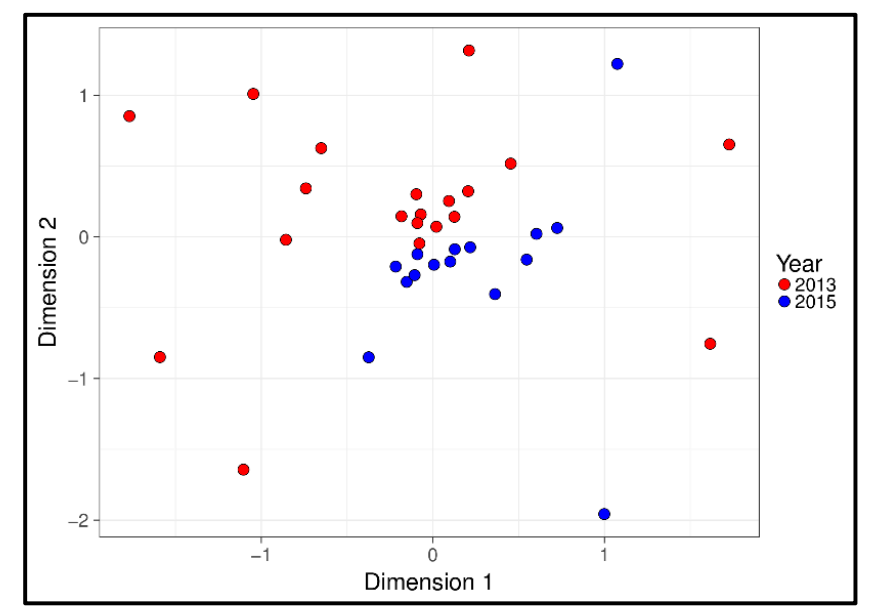

Figure 2. Non-metric multidimensional scaling plot of the bacterial microbiome from muskox faecal samples, produced by 16S DNA metabarcoding. Colour represents the year of sampling, demonstrating clear separation between sampling times.

\subsection{Effect of Location}

When NWGM were included in the MGLM-ANOVA, geographical location of the muskoxen was significantly correlated to bacterial composition, whilst GLM revealed a strong effect on OTU richness (Table 1). However, given the differences in sampling of NWGM, these samples were excluded 
and analyses rerun. Again, a significant effect of geographic location was identified on the bacterial composition, whilst it also had a significant effect on OTU richness (Table 1).

Table 1. Statistical results. Testing the correlation of year of sampling (Year), Sex and weight (Body mass, $\mathrm{kg}$ ) with OTU richness (GLM) and bacterial composition (MGLM-ANOVA), respectively, in faeces from 3 muskoxen populations. Because of biased sampling procedure, the statistical tests were performed \pm Northwest Greenland muskoxen (NWGM).

\begin{tabular}{|c|c|c|c|c|c|}
\hline \multicolumn{6}{|c|}{ NEGM Only $(n=35)$, Biotic and Temporal Effects } \\
\hline \multicolumn{6}{|c|}{ MGLM-ANOVA (Composition) } \\
\hline Variable & Df & Deviance & $p$-value & & \\
\hline Year & 33 & 5584 & 0.002 & & \\
\hline Sex & 32 & 3421 & 0.080 & & \\
\hline Body mass (kg) & 31 & 3951 & 0.048 & & \\
\hline \multicolumn{6}{|c|}{ GLM (OTU Richness) } \\
\hline Variable & Df & Deviance & $\mathrm{AIC}$ & $p$-value & \\
\hline Year & 1 & 120,604 & 392.4 & 0.362 & \\
\hline Sex & 1 & 119,037 & 391.94 & 0.541 & \\
\hline Body mass (kg) & 1 & 117,833 & 391.58 & 0.895 & \\
\hline \multicolumn{6}{|c|}{ Location Effects, All Groups ( \pm NWGM) } \\
\hline \multicolumn{6}{|c|}{ MGLM-ANOVA (Composition) } \\
\hline & Variable & Df & Deviance & $p$-value & \\
\hline Including NWGM & Location & 35 & 3.161 & 0.002 & \\
\hline Excluding NWGM & Location & 35 & 3.161 & 0.002 & \\
\hline \multicolumn{6}{|c|}{ GLM (OTU Richness) } \\
\hline & Variable & Df & Deviance & AIC & $p$-value \\
\hline Including NWGM & Location & 2 & 2.25 & 64.134 & $>0.001$ \\
\hline Excluding NWGM & Location & 2 & 0.464 & -55.579 & $>0.001$ \\
\hline
\end{tabular}

OTU richness was generally greater for NEGM than NM, average richness $=950$ unique OTUs per sample $(S D=64)$ versus average richness per sample $=692$, $(S D=66)$, respectively. The NM samples collectively presented 1143 different OTUs $(n=3)$ vs. 3257 by NEGM $(n=35$, Figure 3$)$ and they shared 903 OTUs between them (representing 28\% of the NEGM total OTUs and 79\% of the NM). Mean richness per sample was lower for NWGM (not fresh samples) than NM and NEGM with an average richness $=507$ and there was greater variation between samples $(\mathrm{SD}=169)$. Total OTU richness of NWGM samples was slightly higher than NM with 1424 unique OTUs, whereof 897 (63\%) were shared with NEGM and NM. OTU richness generally corresponded with the differences in sample size, with the lowest overall richness presented by the smallest sample size (NM) and vice versa.

Firmicutes dominated the bacterial community at the phylum level within the NEGM and NM, with a mean relative abundance of $83 \%(\mathrm{SD}=3.54 \%)$ and $77 \%(\mathrm{SD}=4.7 \%)$ respectively (Figure 4$)$.

NWGM was more heterogeneous in taxonomic composition at phylum level but Firmicutes and Bacteroidetes remained dominant, though the relative abundance of Firmicutes had reduced dramatically and unlike NM and NEGM, Bacteroidetes dominated over Firmicutes (Figures 4 and 5). Clostridia was the dominant class for both NEGM and NM with a mean relative abundance of $82 \%$ $(\mathrm{SD}=3.6 \%)$ and $75 \%(\mathrm{SD}=4.5 \%)$, respectively. Likewise, the dominant order corresponded between NEGM and NM, with Clostridiales comprising $82 \%(\mathrm{SD}=3.6 \%)$ and $75 \%(\mathrm{SD}=4.5 \%)$ of the community respectively. The dominant family for NEGM and NM was Ruminococcaceae with a relative abundance of $60 \%(\mathrm{SD}=4.1 \%)$ and $51 \%(\mathrm{SD}=1.7 \%)$, respectively, representing the majority of the Clostridiales class and Firmicutes phylum. Every other family was below 10\% in relative abundance for NEGM and below 14\% for NM (Spreadsheet S1). 

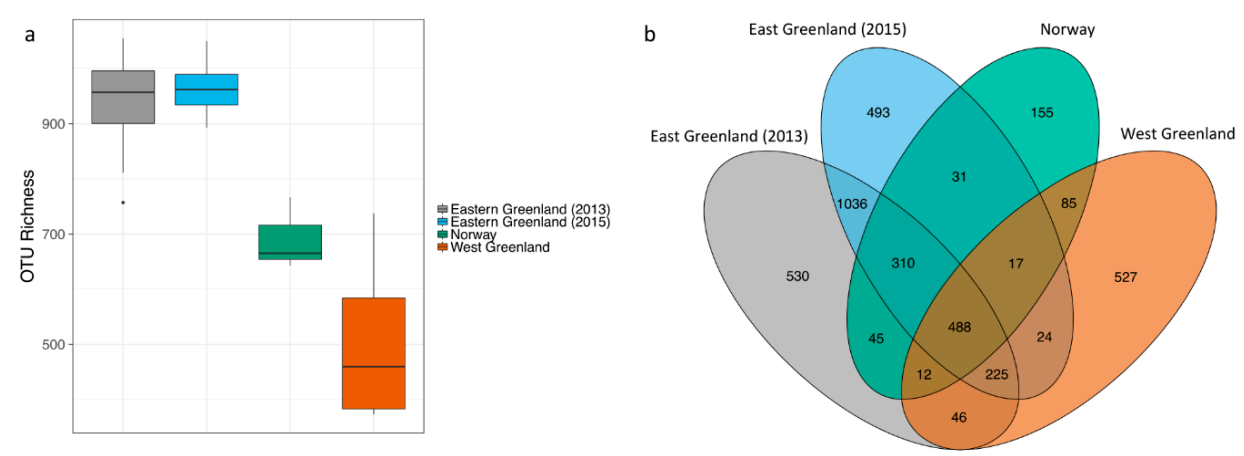

Figure 3. (a) Boxplot of OTU richness between NEGM, NM and NWGM. Line within boxes presents the median; (b) Venn diagram depicting the shared number of OTUs between North East Greenland muskoxen (NEGM), Norwegian muskoxen (NM) and North West Greenland muskoxen (NWGM).

NWGM samples were substantially different from NM and NEGM below phylum level, with a more heterogeneous presentation of families dominated by Flavobacteriaceae by $17 \%$ (SD $=19.3 \%$ ), Ruminococcaceae by $13 \%(\mathrm{SD}=14.9 \%)$ and Sphingobacteriaceae by $10 \%(\mathrm{SD}=8 \%)$ and greater variation between samples.

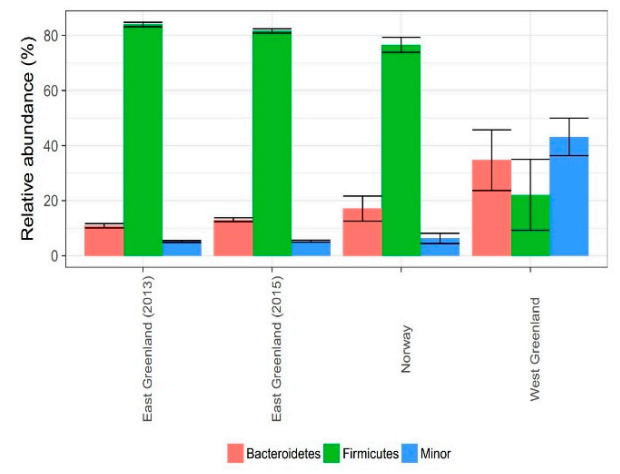

(a)

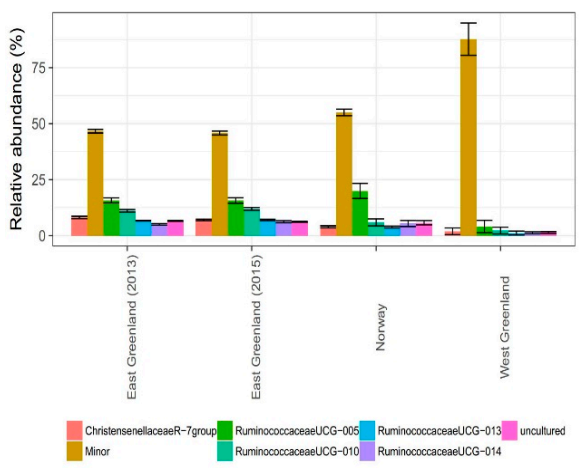

(b)

Figure 4. Taxonomic bacterial composition by relative abundance of (a) phylum; (b) genus.

\subsection{Potential Zoonotic Bacteria}

Thirteen genera of notable zoonotic potential were detected, including Escherichia and/or Shigella, Erysipelothrix, Clostridium, Bacteroides, Bacillus, Actinomyces, Enterobacter, Fusobacterium, Pseudomonas, Rhodococcus, Streptococcus and Yersinia. Species level assignments were generally not determined by the metabarcoding approach, that is, using the V2-V3 16S rRNA region as reference. Table 2 summarizes the potential zoonotic species that these genera comprise. In accordance with its larger sample size, 10 out of 13 zoonotic genera were identified in NEGM samples, yet nine were found in the NWGM samples and seven in the NM samples despite their limited small sizes. The presence of the genera varied considerably between muskoxen groups. Erysipelothrix, Actinomyces and Fusobacterium were for example identified in NEGM but not in NM or NWGM. Yersinia and Rhodococcus were on the other hand not found in NEGM but only in NWGM and NM, respectively (Table 2). The most frequently identified zoonotic genus across samples was Clostridium (35/42) followed by Escherichia/Shigella (28/42) and Bacillus (21/42). For Clostridium, 33 out of 35 total occurrences were identified from NEGM. 2/4 NWGM presented Clostridium OTUs and no Clostridia were found in the samples of NM. For Escherichia/Shigella 25/35 were identified in NEGM, 2/4 from NWGM and 3/3 from NM samples were positive. Lastly, for Bacillus, 16 out of 35 total occurrences originated from NEGM; $1 / 3$ NM samples were positive for Bacillus OTUs and 4/4 NWGM were positive (Table 2). 
Table 2. Zoonotic genera present in the muskoxen faecal samples collected from Northeast Greenland muskoxen (NEGM), West Greenland muskoxen (NWGM) and Norwegian muskoxen (NM). Includes examples of known zoonotic species within each genus as well as comments of risk and epidemiology/epizootiology.

\begin{tabular}{|c|c|c|c|c|c|c|}
\hline \multirow{2}{*}{ Genera } & \multicolumn{3}{|c|}{ Location/No. Animals } & \multirow{2}{*}{ Zoonotic Species Examples } & \multirow{2}{*}{ Disease in Man } & \multirow{2}{*}{ Risk and Epizootiology } \\
\hline & NEGM & NM & NWGM & & & \\
\hline Actinomyces & $4 / 35$ & $0 / 3$ & $0 / 4$ & A. bovis; A. pyogenes & $\begin{array}{l}\text { Abscesses; chronic } \\
\text { bronchopneumonia; sepsis; } \\
\text { endocarditis. }\end{array}$ & $\begin{array}{l}\text { Rare infection in people. Worldwide distribution. } \\
\text { Cows are the main carrier. }\end{array}$ \\
\hline Bacillus & $16 / 35$ & $1 / 3$ & $4 / 4$ & B. anthracis & "Anthrax" & $\begin{array}{l}\text { For man, the source of infection is always infected } \\
\text { animals, contaminated animal products or spores from } \\
\text { originating from infected animals. (Cutaneous) } \\
\text { Infection is for example, known to occur when } \\
\text { skinning or butchering an animal or by contact with } \\
\text { infected leather, pelts, wool, or fur. Broken dermis } \\
\text { favours transmission. (Gastrointestinal) infection can } \\
\text { be acquired from consumption of domestic and wild } \\
\text { animals. Animals mainly become infected by ingestion } \\
\text { of pasture or water that have been contaminated with } \\
\text { spores- -typically in the vicinity of anthrax-infected } \\
\text { carcasses as dead and dying animals are the vessel of } \\
\text { high rate of replication of B. anthracis. The bacilli } \\
\text { sporulate if the carcass is opened and they contaminate } \\
\text { the surrounding environment, leading to new } \\
\text { infections in particularly grazing animals. Infected } \\
\text { animals and especially birds can effectively transport } \\
\text { the infection to other areas. Transmission between } \\
\text { humans is a rare form of infection for humans. }\end{array}$ \\
\hline Bacteroides & $35 / 35$ & $3 / 3$ & $3 / 4$ & $\begin{array}{c}\text { Bacteroides sp.; B. fragilis; B. tectus; } \\
\text { B. ovatus }\end{array}$ & Wound infections & $\begin{array}{l}\text { Unknown species of Bacteroides associated with } \\
\text { purulent wound infection from a horse bite. Wound } \\
\text { infections with other species of Bacteroides associated } \\
\text { with cats and dogs. }\end{array}$ \\
\hline Clostridium & $33 / 35$ & $1 / 3$ & $1 / 4$ & C. difficile; C. perfringens & Gastroenteritis & $\begin{array}{l}\text { Both types are regarded as potential zoonoses. } \\
\text { Infection is acquired from the environment, from } \\
\text { contact or ingestion of contaminated } \\
\text { meat/animals/animal products [39]. }\end{array}$ \\
\hline Erysipelothrix & $15 / 35$ & $0 / 3$ & $0 / 4$ & & $\begin{array}{l}\text { Dermatitis; septic arthritis; } \\
\text { endocarditis; sepsis }\end{array}$ & $\begin{array}{l}\text { The course of disease usually only lasts for up to four } \\
\text { weeks but sepsis with potential subsequent } \\
\text { endocarditis can occur. Distributed Worldwide in a } \\
\text { wide range of species incl. domestic animals, for } \\
\text { example, swine and ruminants and frequently } \\
\text { associated with fish. Many animals carry the disease } \\
\text { non-symptomatically. People can acquire the infection } \\
\text { through handling of infected animal products. }\end{array}$ \\
\hline
\end{tabular}


Table 2. Cont

\begin{tabular}{|c|c|c|c|c|c|c|}
\hline \multirow{2}{*}{ Genera } & \multicolumn{3}{|c|}{ Location/No. Animals } & \multirow{2}{*}{ Zoonotic Species Examples } & \multirow{2}{*}{ Disease in Man } & \multirow{2}{*}{ Risk and Epizootiology } \\
\hline & NEGM & NM & NWGM & & & \\
\hline Escherichia/Shigella & $23 / 35$ & $3 / 3$ & $2 / 4$ & E. coli $(\mathrm{VTEC} \text { and EHEC })^{1}$ & Enteritis & $\begin{array}{l}\text { Infection through faecal-oral route, commonly from } \\
\text { contaminated animal products. Airborne transmission } \\
\text { via dust is also possible. EHEC infections in humans } \\
\text { often associated with cattle which are considered a } \\
\text { reservoir species. VTEC infections associated with both } \\
\text { cattle, sheep among other. }\end{array}$ \\
\hline Fusobacterium & $10 / 35$ & $0 / 3$ & $0 / 4$ & $\begin{array}{l}\text { F. nucleatum; F. necrophorum (not } \\
\text { confirmed) }\end{array}$ & Wound infections & $\begin{array}{l}\text { Infection risk associated biting events or contamination } \\
\text { of open skin lesions or through mucus membranes. } \\
\text { Previously predominantly associated with dog bite. }\end{array}$ \\
\hline Mycobacterium & $2 / 35$ & $0 / 3$ & $2 / 4$ & $\begin{array}{l}\text { Principally } M . \text { bovis in terms of } \\
\text { zoonoses; M. avium subsp. } \\
\text { paratuberculosis; M. simiae; } M \text {. } \\
\text { kansasii; M. ulcerans }\end{array}$ & $\begin{array}{l}\text { Pulmonary and } \\
\text { extrapulmonary forms. The } \\
\text { latter affecting glands, bones } \\
\text { and joints, meninges, urinary } \\
\text { tracts and more. }\end{array}$ & $\begin{array}{l}\text { Mycobacterium spp. vary with host-species but zoonotic } \\
\text { Mycobacterium spp. can generally infect a wide range of } \\
\text { animal species and are considered to be distributed } \\
\text { virtually Worldwide. } \\
\text { These bacteria can be difficult to kill in the environment } \\
\text { as they are resistant to many common disinfectants as } \\
\text { well as desiccation. } \\
\text { Pasteurization of milk has however reduced the } \\
\text { incidences of zoonotically acquired infections. Infection } \\
\text { can however also be acquired through inhalation. Main } \\
\text { reservoir of } M \text {. bovis is cattle. The infection with } M \text {. } \\
\text { bovis comes from animal sources since human to } \\
\text { human transmission is considered rare. }\end{array}$ \\
\hline Pasteurella & $0 / 35$ & $1 / 3$ & $0 / 4$ & P. multocida & $\begin{array}{l}\text { Disease often associated with } \\
\text { bite wounds; abscesses; } \\
\text { cellulitis; meningitis; septic } \\
\text { arthritis; osteomyelitis; } \\
\text { respiratory tract disease; sepsis } \\
\text { and endocarditis are rare }\end{array}$ & $\begin{array}{l}\text { Infection is typically acquired through bite wounds but } \\
\text { can also occur through inhalation and the digestive } \\
\text { tract. Cats and dogs are frequent carriers but cattle and } \\
\text { sheep and other also present important asymptomatic } \\
\text { reservoirs. Many wild animals are also asymptomatic } \\
\text { carriers and outbreaks in wildlife occur occasionally. } \\
\text { Pasteurella is believed only to survive shortly in the } \\
\text { environment and animals therefore play a key role in } \\
\text { the epidemiology and infection of Pasteurella in people. } \\
\text { Infection between humans are also thought to occur. }\end{array}$ \\
\hline
\end{tabular}


Table 2. Cont.

\begin{tabular}{|c|c|c|c|c|c|c|}
\hline \multirow{2}{*}{ Genera } & \multicolumn{3}{|c|}{ Location/No. Animals } & \multirow{2}{*}{ Zoonotic Species Examples } & \multirow{2}{*}{ Disease in Man } & \multirow{2}{*}{ Risk and Epizootiology } \\
\hline & NEGM & NM & NWGM & & & \\
\hline $\begin{array}{l}\text { Rhodococcus } \\
\quad \text { (syn. } \\
\text { Coryne-bacterium) }\end{array}$ & $0 / 35$ & $0 / 3$ & $2 / 4$ & R. equi & $\begin{array}{l}\text { A rare disease in humans and } \\
\text { often associated with } \\
\text { immuno-suppressive states; } \\
\text { but neglected reporting is } \\
\text { suspected; granulomatous and } \\
\text { suppurative lung disease; } \\
\text { Pulmonary (most prevalent } \\
\text { form) and extra-pulmonary } \\
\text { form including osteomyelitis; } \\
\text { cachexia; bloody diarrhoea; } \\
\text { abscessation and other. }\end{array}$ & $\begin{array}{l}\text { A saprophyte reported Worldwide which replicates } \\
\text { effectively in faeces from herbivores such as goats, } \\
\text { sheep, cows, deer, horses, cats and dogs. Often isolated } \\
\text { from horses and a significant disease of foals. Infection } \\
\text { in humans occurs through inhalation of the pathogen, } \\
\text { often mediated by dust-particles or through infection of } \\
\text { for example, infected sputum. Acetic acid in faeces is } \\
\text { believed to favour effective replication of Rhodococcus } \\
\text { in faeces. The main reservoir is as such soil exposed to } \\
\text { faeces from herbivores which shed high amount of } \\
\text { acetic acid in their faeces [ } 40,41] \text {. }\end{array}$ \\
\hline Streptococcus & $11 / 35$ & $3 / 3$ & $2 / 4$ & $\begin{array}{l}\text { S. bovis; S. suis; S. zooepidemicus } \\
\text { (Lancefield group D and C } \\
\text { respectively) }\end{array}$ & $\begin{array}{l}\text { S. suis: meningitis; arthritis and } \\
\text { endophthalmitis; } S \text {. } \\
\text { zooepidemicus: pneumonia; } \\
\text { endocarditis; meningitis; } \\
\text { pericarditis; exudative } \\
\text { pharyngitis; tonsillitis. }\end{array}$ & $\begin{array}{l}\text { Ingestion of for example, raw milk or pork meat and } \\
\text { handling of infected animals are related risks. S. } \\
\text { zooepidemicus is a commensal of the skin on, upper } \\
\text { respiratory tract and in the tonsils of various animal } \\
\text { species. It causes multiples diseases in horses and is } \\
\text { implicated in mastitis of cattle. S. suis is a highly } \\
\text { occupational disease in relation to slaughterhouses and } \\
\text { butchering and believed most often to be acquired } \\
\text { through the skin. }\end{array}$ \\
\hline Yersinia & $0 / 35$ & $0 / 3$ & $2 / 4$ & Y. enterocolitica & $\begin{array}{l}\text { Enteritis and acute diarrhoea; } \\
\text { reactive arthritis; nodular } \\
\text { erythema }\end{array}$ & $\begin{array}{l}\text { Worldwide distribution and isolated broadly in the } \\
\text { environment: from animals, food and water. } \\
\text { Can occur sporadically or as epidemics. Faecal-oral } \\
\text { route of transmission from other people or from } \\
\text { contaminated animal products. Occupation involving } \\
\text { swine, consumption of pork and milk products are } \\
\text { associated with zoonotic transmission to people. }\end{array}$ \\
\hline
\end{tabular}

${ }^{1}$ VTEC $=$ Vero-toxin Producing E. coli $;$ EHEC $=$ Enterohemorrhagic E. coli 
Moreover, OTUs were assigned to 41 genera associated with human infections (not generally classified as "zoonoses") were identified by the SILVA database (Table S1).

\section{Discussion}

\subsection{Physiological and Temporal Effects}

The bacterial composition of NEGM were tested against three parameters: body mass, year of sampling and sex and significant effects of body mass and year of sampling were found. Changes in body mass could be associated with the animal's age and age-related development of the gut microbial composition in muskoxen. Jami et al. [42] found that it takes at least two years for the bovine gut bacterial community to mature and similar findings have been shown for humans [43,44]. Here, the muskoxen were determined as older than two years old but it remains unknown, when, the gut microbial community reaches maturity in high Arctic muskoxen. Changes in gut microbial community associated with changes in weight could be a reflection of bacterial community influence on the animal's energy metabolism [45], or they could simply be a result of consuming more energy-rich pastures. Gut bacterial composition has been linked to the health of cows $[45,46]$ and being malnourished has significant effects on the gut microbial communities of many animals [47-49]. Therefore, the observed changes in the muskox gut bacteria might also be driven by- or impacting upon fitness.

The effect of temporal variation on the gut bacterial community is a feature shared with other animals [50-52] and likely reflects changes to their surrounding ecosystem such as feed availability $[53,54]$. For example, the feed intake by reindeer fluctuates by a factor of $3-4$ times as much in summer compared to winter, with significant effects on their gut bacterial community $[49,55]$ and similar findings are reported in muskoxen [56-58]. Our samples were collected in the same time of year but could be impacted by inter-annual climate variations, such as prolonged periods of a warm climate. It has been reported that increased temperatures and humidity correlate with changes in gut microbial diversity in cows [59] and is of considerable interest within the muskox given the large environmental changes currently underway in the Arctic. Furthermore, the composition of the gut bacterial community, specifically a high Firmicutes/Bacteroidetes ratio in the rumen, has been found to correlate with higher fat content in milk [45], a factor of high importance for the new-born muskoxen in the high Arctic. This aspect can however not be directly reflected in our results as there are significant variation between ruminal and faecal samples (see more on this below) but it is indicative of potentially broad physiological changes brought about by changes to the gut microbial community.

The phyla Firmicutes and Bacteroidetes dominated the faecal bacterial community of NEGM. Both are effective degraders of complex fibres and they are typical phyla to dominate the faecal microbiome across multiple species and types of digestive tracts, for example, cattle, horses and humans [60-63]. The principle role of Bacteroidetes is degradation of complex carbohydrates into butyrate in the large intestine. The substrate of Bacteroides is among other cellulose, xylan and pectin but also host-derived gastrointestinal carbohydrates such as mucin $[64,65]$. Firmicutes were dominated by the order Clostridiales which has been regarded as taking a pivotal role in the degradation and fermentation of cellulose in the large intestine by the secretion and cell-surface incorporation of several well-known cellulases [64]. The dominant family within the Clostridiales was Ruminococcaceae; a family with the ability to degrade otherwise recalcitrant polysaccharides such as complex fibres [66]. Therefore the muskox gut bacterial community seems well adapted to a highly lignified plant diet found within the high Arctic $[4,53]$.

\subsection{Effect of Location}

Location of the muskoxen herds had the greatest effect on both gut bacterial composition as well as richness, even when the dried NWGM faecal samples were excluded. The effects of year of sampling and body mass on the NEGM were relatively small compared to effects of location. Ishaq et al. [67] 
found similar effects in moose (Alces alces) across three Arctic areas; their study however focused on ruminal samples instead of faecal (more on this type of comparison below).

The microbial compositions of NEGM and NM were considerably more similar than NWGM (Figures 4 and 5). Vogtmann et al., 2017 [68] compared the microbiomes of faecal samples frozen immediately after sampling with samples left at ambient temperature for 4 days prior to freezing and found that results were relatively stable. The results of NWGM are nevertheless regarded as most likely being a consequence of the differing sampling technique, with the vast difference between NWGM and NM/NEGM communities far exceeding expected community variation. For example, Firmicutes dominates faecal bacterial communities across mammal species but the Bacteroidetes/Firmicutes ratio was reversed in NWGM and there were increases in aerobic bacteria known to occur in the Arctic environment (Flavobacteriales and Sphingobacteriales), indicating environmental contamination $[69,70]$. This raises questions about using dried (delayed sampling from dropping) faecal samples in characterizing the gut-associated microbial communities [71,72] and we therefore recommend interpreting microbial community data produced from dried faecal samples cautiously.
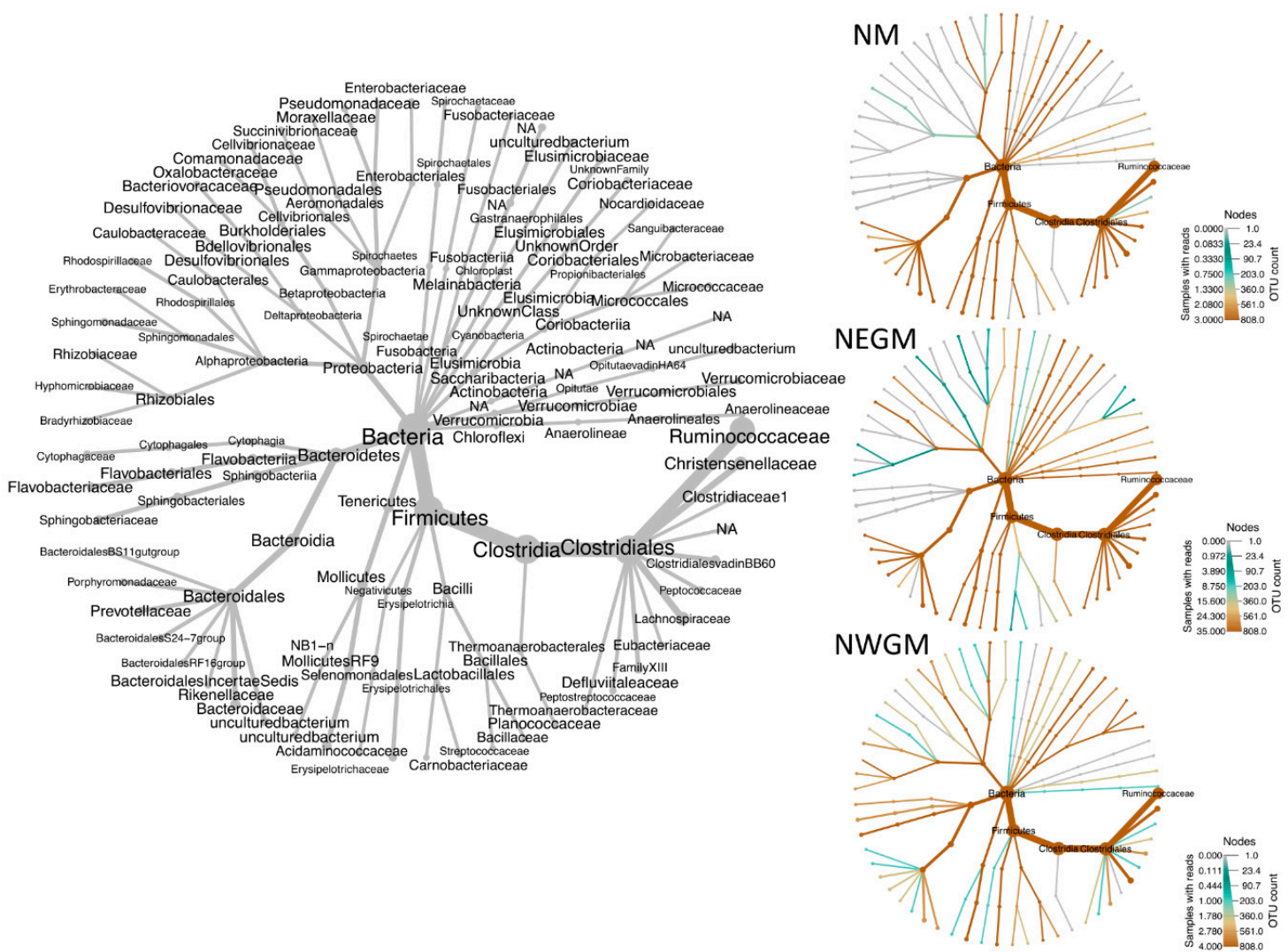

Figure 5. Heat map trees of the bacterial community detected by 16S-rDNA metagenomic sequencing from faecal samples of Norwegian muskoxen (NM), Northeast Greenland muskoxen (NEGM) and Northwest Greenland muskoxen (NWGM). (Left) Taxonomic assignments of branches, kingdom-family level; (Right) heat map trees for each location sampled. Note the color-coded density scales on the right.

Overall, relative abundances between NEGM and NM were comparable. At family level, the relative abundance of Ruminococcaceae was approximately 10\% higher in NEGM than NM; and while this could merely be an effect of a small sample size for NM, an increase of fibre intake has been associated with an increase of Ruminococcus species in the hindgut of goats [73] and Ruminococcaceae are known as highly effective degraders of recalcitrant polysaccharides $[66,74]$. 
An increase in Firmicutes have also been found in faeces of cattle in association with a high-fibre diet [75]; the increase in relative abundance of Firmicutes in NEGM was however only slight compared to NM. These observations could be an indication of a higher fibre-intake of NEGM compared to NM but more studies are needed. Diet is however one of the strongest effectors on the gut microbial community [11-13,74,76]. The muskoxen in Northeast Greenland feed mostly on graminoids (approximately $80 \%$ of their diet) and shrubs such as Salix spp. [4,7], while the diet of the muskoxen on the island Ryøya at the coast of northern Norway is dominated by natural pastures of heather in open birch and pine forest with patches of grassland [16,77]. During wintertime the Norwegian muskoxen on Ryøya are also fed hay to support their forage needs [77]. The climate is warmer and characterized by more precipitation in Tromsø compared to Northeast Greenland [78,79] and Davidson et al. [18] suggest the use of Norwegian muskoxen as early warning sentinels of climate change.

The main difference between NEGM and NM was mean OTU richness per sample, which was significantly lower for NM. All the muskoxen sampled recently originated from, or have been introduced from East Greenlandic population [25] and moreover, genetic diversity is known to be extremely low for muskoxen [80,81]. In evolutionary and genetic terms, this will likely limit the influence of host genotypic variation on the gut microbial community. As discussed above for differences in relative abundances, diet is very likely an important factor in the difference in OTU richness between NEGM and NM. Bacterial richness is generally dependent on microbiota-accessible carbohydrates [82] and there are several studies finding an effect of increased faecal bacterial richness with increased fibre intake across mammal species including ruminants [83-87]. Some studies however fail to detect this association [88-90]. Research is on the other hand less ambiguous when it comes the importance of intestinal microbial composition and diversity for dietary efficacy [91-93].

Sequencing the V2-V3 region of the 16S gene in the faecal samples from the Ryøya muskoxen (NM) in this present study gave similar results as those reported by Salgado-Flores et al. [16] sequencing the V1-V3 region, with the Firmicutes and Bacteroidetes dominating their faecal bacterial communities at phylum level with approximately $80 \%$ and $20 \%$ relative abundance, respectively. The Ruminococcaceae were the dominant family with a relative abundance of $51 \%(\mathrm{SD}=1.7)$ for $\mathrm{NM}$ and $61 \%(\mathrm{SD}=4.1)$ for NEGM. However, the longer amplicon lengths used in this study also allowed for a greater proportion of the Ruminococcaceae to be taxonomically assigned to genus or family, with just $7.4 \%$ of the Ruminococcaceae OTUs assigned only to family level and between 25-39\% in the study performed by Salgado-Flores and colleagues. It also meant that the percentage of reads unassigned to genus level dropped from approximately $55 \%$ to $16 \%$ in this study.

Lastly, we wish to note that the majority of studies of ruminants have focused directedly on ruminal microbiomes as opposed to faecal, leaving our results not directly comparable to foregut microbial community composition. Based on our DNA-based approach, we cannot know if the template DNA detected originate from viable bacteria and detected OTUs may represent live or dead bacteria from ascending segments of the digestive tract. It has moreover been shown that many of the same taxa are present across the length of the intestinal tract but at variable abundances [94], with for example the Firmicutes/Bacteroidetes ratio shown to significantly increase in faecal- compared to ruminal samples [95]. As such studies have also shown that faecal samples best reflect the bacterial composition of the distal hindgut $[96,97]$.

\subsection{Potential Zoonotic Bacteria}

Due to the limitations of the metabarcoding, species level assignments were not made, however 13 genera generally accepted as zoonoses were identified (Table 2). In addition to these, 41 genera involved in human infections were identified (Table S1).

Muskoxen are hunted and consumed from Midwest to Northwest Greenland and certain areas of Mideast Greenland. Norwegian muskoxen are generally protected and only very rarely consumed, with the muskoxen of Ryøya being used solely for research and not consumed. Muskoxen have recently been drawn into focus because of the commercial slaughter in West Greenland and the 
findings of zoonotic Giardia duodenalis assemblage A (parasite/protozoan) in muskoxen herds across the Arctic [98,99]. A severe case of Q-fever (Coxiella burnetii) in a Greenlandic man associated with muskoxen has been reported [21], whilst they also serve as hosts for parasitic zoonoses such as Echinococcus spp. [100,101]. Coxiella was not detected in this study but placental secretions or serology may be better means for its detection [102]. Other examples of zoonoses that have been reported as being associated with muskoxen elsewhere, are: Erysipelothrix rhusiopathiae, Chlamydophila spp., Brucella suis biovar 4 and Yersinia pseudotuberculosis [103-106], with Erysipelothrix and Yersinia-assigned OTUs detected in this work.

The greatest risk of infection in the case of these muskoxen would likely arise from contact or ingestion of with water contaminated by faeces, or edible tissues likewise contaminated with intestinal contents. Standard hygienic measures in relation to butchering and handling will be effective in terms of food safety, though feasibility of its practical application in the current Arctic situation must be taken into consideration. Another considerable risk of infection from zoonoses is the contamination of fresh water from carcasses, such as in the case of Bacillus anthracis, Pseudomonas mallei and Yersinia spp. (Table 2).

It should be noted that the zoonotic genera identified here have variable zoonotic potential within the muskoxen (Table 2). It is for example less likely that they carry typically zoonotic Escherichia species/strains (such as verotoxin producing E. coli, VTEC) [107] compared to other relatively avirulent strains. Although zoonotic E. coli O:157 have been found in wildlife, studies have failed to detect significant reservoirs in northern mammalian wildlife [108,109]. Furthermore, Escherichia is a normal bacterial inhabitant of the intestinal flora of mammals and a genus which holds several species, where only few, like certain E. coli types, are regarded as zoonotic and this species itself comprises an extreme degree of diversity of which only a handful are regarded zoonotic [110,111]. Other more likely zoonoses to take reservoir in these muskoxen are E. rhusiopathiae, Y. pseudotuberculosis, Clostridium difficile/perfringens, Bacillus cereus, Pasteurella multocida and Mycobacterium bovis since these occur in (wild) animal reservoirs [37,112-114] and have been specifically found in Arctic species (incl. muskoxen) $[105,115,116]$; and/or can survive in the environment for prolonged periods of time [37,117-121].

Some zoonotic bacteria also present a serious health threat to the muskoxen, such as C. burnetii (causing abortions among other), E. rhusiopathiae and Y.pseudotuberculosis. The latter two have caused mass mortality of muskoxen. Recently, E. rhusiopathiae was confirmed from carcasses of a mass mortality event of ca. 150 muskoxen in Canada [105] but it has also been implicated in other mortality events between 2009-2013 with occurrences stretching across $>200,000 \mathrm{~km}^{2}$. Kutz et al. [105] found that the mass die offs were compatible with the introduction of a new strain of the pathogen to naïve populations, underscoring the vulnerability of the muskoxen in a changing Arctic and that E. rhusiopathiae could be implicated in declining populations of muskoxen in Canada. Events of pathogen introduction to naïve populations are expected to increase with climate change [18] and temperature increases 2-3 degrees above average were recorded prior to at least two outbreaks of E. rhusiopathiae on Victoria Island, Canada and non-specific pneumonias have been related to high temperatures in Norway and in captivity [116,122]. The low genetic diversity found within modern muskoxen populations includes a low variability of the Major Histocompatibility Complex (MHC) genes $[80,81,123]$ that could negatively influence their immune responses. Interestingly, both of the mass die-off associated Yersinia and Erysipelothrix were identified in the current study. Whether these genera present pathogenic and/or zoonotic species is unknown but provides some insight into the likelihood of these muskoxen as carriers and animal health related risks including mass die-offs. In spite of the small sample sizes of NM and NWGM, Yersinia was only identified in NWGM and Erysipelothrix in NM only; this again underscores the effect of the habitat on the microbial gut community and thereby zoonotic potential.

The detection of genera such as Rhodococcus, detected in NWGM only, may arise on behalf of delayed sampling from dropping, which may have led to contamination of environmental bacteria 
and changes in the bacterial community. Rhodococcus is correspondingly a common soil bacterium and obligate aerobe. It may however also have been a transient member of the gut microbial community and (potentially its fragmented DNA) passed with the feces [124].

More studies that permit the identification of species and strains where relevant, are needed to further elucidate this subject and inform hunters and wildlife biologists about zoonotic risk and wildlife health.

\section{Conclusions}

Muskoxen have diverse gut bacterial communities dominated by the phylum Firmicutes. Their gut bacterial communities are affected by changes in the host habitat and bacterial composition is related to a broad range of physiological functions. Location had the largest measured effect on the gut community, whilst there was significant community variation within populations (with body mass and inter-annual variation effecting both richness and composition) but the effects of these were comparatively small. Sampling technique (fresh vs. dried) however, most probably, had the greatest effect on the community composition. A total of 13 genera comprising generally accepted zoonotic bacterial species were identified from the faecal samples and muskoxen may be a substantial reservoir of zoonoses. However, it remains unknown whether these genera represent a significant risk of zoonotic infection for humans and further molecular work identifying zoonotic bacteria to species level is needed.

Supplementary Materials: The following are available online at http:/ /www.mdpi.com/2076-2607/6/3/76/s1, Table S1: bacterial genera associated with human infections detected in muskoxen feces. Spreadsheet S1: muskoxen faecal 16S rRNA metabarcoding, data.

Author Contributions: Initials: E.U.A.-R.; C.J.B.; L.R.; A.S.-F.; M.A.S.; C.G.; J.B.M.; N.M.S.; A.J.H.; C.S. Contributions: Conceptualization: E.U.A.-R., C.S., A.J.H., N.M.S.; Methodology: E.U.A.-R., C.J.B., L.R., A.J.H.; Software: C.J.B.; Validation: C.J.B., L.R.; Formal Analysis: C.J.B., E.U.A.-R.; Investigation: E.U.A.-R., C.J.B.; Resources: N.M.S., M.A.S., A.S.-F., C.S., A.J.H., C.G.; Data Curation: C.J.B.; Writing-Original Draft Preparation: E.U.A.-R., C.J.B.; Writing-Review \& Editing: E.U.A.-R., C.J.B., L.R., A.S.-F., M.A.S., C.G., J.B.M., N.M.S., A.J.H., C.S.; Visualization: C.J.B., E.U.A.-R.; Supervision: C.S., A.J.H., M.A.S., N.M.S.; Project Administration: C.S., E.U.A.R.; Funding Acquisition: C.S., E.U.A.-R., A.J.H., C.J.B., N.M.S., J.B.M., C.G., M.A.S., A.S.-F.

Funding: This research was funded by Copenhagen Zoo Research Foundation, Nordic Council of Ministers (Norden), grant numbers: A15008 and A16081. C.J.B. was supported by the Aage V. Jensens Foundations, Denmark (112172).

Acknowledgments: Hans E. Lian and Elin Olsson are thanked for their help with sampling the muskoxen at Ryøya, Norway.

Conflicts of Interest: The authors declare no conflict of interest.

\section{References}

1. Kutz, S.; Rowell, J.; Adamczewski, J.; Gunn, A.; Cuyler, C.; Aleuy, O.A.; Austin, M.; Berger, J.; Blake, J.; Bondo, K. Muskox Health Ecology Symposium 2016: Gathering to Share Knowledge on Umingmak in a Time of Rapid Change. Arctic 2017, 70, 225-236. [CrossRef]

2. Mosbacher, J.B. Ecology of a High Arctic Key Species: Muskoxen in Northeast Greenland. Ph.D. Thesis, Aarhus University, Roskilde, Denmark, 2017.

3. Klein, D.R.; Bay, C. Diet selection by vertebrate herbivores in the high arctic of Greenland. Ecography 1991, 14, 152-155. [CrossRef]

4. Kristensen, D.K.; Kristensen, E.; Forchhammer, M.C.; Michelsen, A.; Schmidt, N.M. Arctic herbivore diet can be inferred from stable carbon and nitrogen isotopes in C3 plants, faeces, and wool. Can. J. Zool. 2011, 89, 892-899. [CrossRef]

5. Thing, H.; Klein, D.R.; Jingfors, K.; Holt, S. Ecology of muskoxen in Jameson Land, northeast Greenland. Ecography 1987, 10, 95-103. [CrossRef]

6. Mosbacher, J.B.; Kristensen, D.K.; Michelsen, A.; Stelvig, M.; Schmidt, N.M. Quantifying Muskox Plant Biomass Removal and Spatial Relocation of Nitrogen in a High Arctic Tundra Ecosystem. Arct. Antarct. Alp. Res. 2016, 48, 229-240. [CrossRef] 
7. Schmidt, N.M.; Mosbacher, J.B.; Vesterinen, E.J.; Roslin, T.; Michelsen, A. Limited dietary overlap amongst resident Arctic herbivores in winter: Complementary insights from complementary methods. Oecologia 2018, 1-11. [CrossRef] [PubMed]

8. Bergman, E.N. Energy contributions of volatile fatty acids from the gastrointestinal tract in various species. Physiol. Rev. 1990, 70, 567-590. [CrossRef] [PubMed]

9. Carroll, E.J.; Hungate, R.E. The Magnitude of the Microbial Fermentation in the Bovine Rumen. Appl. Microbiol. 1954, 2, 205-214. [PubMed]

10. Munn, A.J.; Barboza, P.S. Could a big gut be too costly for muskoxen (Ovibos moschatus) in their first winter? Zoology 2008, 111, 350-362. [CrossRef] [PubMed]

11. Carmody, R.N.; Gerber, G.K.; Luevano, J.M.; Gatti, D.M.; Somes, L.; Svenson, K.L.; Turnbaugh, P.J. Diet Dominates Host Genotype in Shaping the Murine Gut Microbiota. Cell Host Microbe 2015, 17, $72-84$. [CrossRef] [PubMed]

12. Kim, M.; Kim, J.; Kuehn, L.A.; Bono, J.L.; Berry, E.D.; Kalchayanand, N.; Freetly, H.C.; Benson, A.K.; Wells, J.E. Investigation of bacterial diversity in the feces of cattle fed different diets. J. Anim. Sci. 2014, 92, 683-694. [CrossRef] [PubMed]

13. Shanks, O.C.; Kelty, C.A.; Archibeque, S.; Jenkins, M.; Newton, R.J.; McLellan, S.L.; Huse, S.M.; Sogin, M.L. Community Structures of Fecal Bacteria in Cattle from Different Animal Feeding Operations. Appl. Environ. Microbiol. 2011, 77, 2992-3001. [CrossRef] [PubMed]

14. Salgado-Flores, A.; Hagen, L.H.; Ishaq, S.L.; Zamanzadeh, M.; Wright, A.-D.G.; Pope, P.B.; Sundset, M.A. Rumen and cecum microbiomes in reindeer (Rangifer tarandus tarandus) are changed in response to a lichen diet and may affect enteric methane emissions. PLoS ONE 2016, 11, e0155213. [CrossRef] [PubMed]

15. Qi, M.; Wang, P.; O’Toole, N.; Barboza, P.S.; Ungerfeld, E.; Leigh, M.B.; Selinger, L.B.; Butler, G.; Tsang, A.; McAllister, T.A. Snapshot of the eukaryotic gene expression in muskoxen rumen-A metatranscriptomic approach. PLoS ONE 2011, 6, e20521. [CrossRef] [PubMed]

16. Salgado-Flores, A.; Bockwoldt, M.; Hagen, L.H.; Pope, P.B.; Sundset, M.A. First insight into the faecal microbiota of the high Arctic muskoxen (Ovibos moschatus). Microb. Genom. 2016, 2. [CrossRef] [PubMed]

17. Wang, G.; Luo, H.; Meng, K.; Wang, Y.; Huang, H.; Shi, P.; Pan, X.; Yang, P.; Diao, Q.; Zhang, H.; et al. High Genetic Diversity and Different Distributions of Glycosyl Hydrolase Family 10 and 11 Xylanases in the Goat Rumen. PLoS ONE 2011, 6, e16731. [CrossRef] [PubMed]

18. Davidson, R.; Simard, M.; Kutz, S.J.; Kapel, C.M.; Hamnes, I.S.; Robertson, L.J. Arctic parasitology: Why should we care? Trends Parasitol. 2011, 27, 239-245. [CrossRef] [PubMed]

19. Hotez, P.J. Neglected Infections of Poverty among the Indigenous Peoples of the Arctic. PLoS Negl. Trop. Dis. 2010, 4, e606. [CrossRef] [PubMed]

20. Jenkins, E.J.; Castrodale, L.J.; de Rosemond, S.J.C.; Dixon, B.R.; Elmore, S.A.; Gesy, K.M.; Hoberg, E.P.; Polley, L.; Schurer, J.M.; Simard, M.; et al. Chapter Two-Tradition and Transition: Parasitic Zoonoses of People and Animals in Alaska, Northern Canada, and Greenland. In Advances in Parasitology; Rollinson, D., Ed.; Academic Press: Cambridge, MA, USA, 2013; Volume 82, pp. 33-204.

21. Koch, A.; Svendsen, C.B.; Christensen, J.J.; Bundgaard, H.; Vindfeld, L.; Christiansen, C.B.; Kemp, M.; Villumsen, S. Q Fever in Greenland. Emerg. Infect. Dis. 2010, 16, 511-513. [CrossRef] [PubMed]

22. Pufall, E.L.; Jones, A.Q.; McEwen, S.A.; Lyall, C.; Peregrine, A.S.; Edge, V.L. Perception of the importance of traditional country foods to the physical, mental, and spiritual health of Labrador Inuit. Arctic 2011, 64, 242-250. [CrossRef]

23. Schmidt, N.M.; van Beest, F.M.; Mosbacher, J.B.; Stelvig, M.; Hansen, L.H.; Nabe-Nielsen, J.; Grøndahl, C. Ungulate movement in an extreme seasonal environment: Year-round movement patterns of high-arctic muskoxen. Wildl. Biol. 2016, 22, 253-267. [CrossRef]

24. Olesen, C.R.; Thing, H. Guide to field classification by sex and age of the muskox. Can. J. Zool. 1989, 67, 1116-1119. [CrossRef]

25. Thulin, C.-G.; Englund, L.; Ericsson, G.; Spong, G. The impact of founder events and introductions on genetic variation in the muskox Ovibos moschatus in Sweden. Acta Theriol. 2011, 56, 305-314. [CrossRef]

26. Takahashi, S.; Tomita, J.; Nishioka, K.; Hisada, T.; Nishijima, M. Development of a prokaryotic universal primer for simultaneous analysis of bacteria and archaea using next-generation sequencing. PLoS ONE 2014, 9, e105592. [CrossRef] [PubMed] 
27. Rognes, T.; Flouri, T.; Nichols, B.; Quince, C.; Mahé, F. VSEARCH: A versatile open source tool for metagenomics. Peer] 2016, 4, e2584. [CrossRef] [PubMed]

28. Martin, M. Cutadapt removes adapter sequences from high-throughput sequencing reads. EMBnet J. 2011, 17, 10-12. [CrossRef]

29. Schnell, I.B.; Bohmann, K.; Gilbert, M.T.P. Tag jumps illuminated-reducing sequence-to-sample misidentifications in metabarcoding studies. Mol. Ecol. Resour. 2015, 15, 1289-1303. [CrossRef] [PubMed]

30. Edgar, R.C. Search and clustering orders of magnitude faster than BLAST. Bioinformatics 2010, 26, $2460-2461$. [CrossRef] [PubMed]

31. Quast, C.; Pruesse, E.; Yilmaz, P.; Gerken, J.; Schweer, T.; Yarza, P.; Peplies, J.; Glöckner, F.O. The SILVA ribosomal RNA gene database project: Improved data processing and web-based tools. Nucleic Acids Res. 2012, 41, D590-D596. [CrossRef] [PubMed]

32. Caporaso, J.G.; Kuczynski, J.; Stombaugh, J.; Bittinger, K.; Bushman, F.D.; Costello, E.K.; Fierer, N.; Pena, A.G; Goodrich, J.K.; Gordon, J.I. QIIME allows analysis of high-throughput community sequencing data. Nature Methods 2010, 7, 335.

33. Team, R.C. R: A Language and Environment for Statistical Computing. 2013. Available online: http:/ / softlibre.unizar.es/manuales/aplicaciones/r/fullrefman.pdf (accessed on 1 November 2017).

34. Oksanen, J.; Kindt, R.; Legendre, P.; O’Hara, B.; Stevens, M.H.H.; Oksanen, M.J.; Suggests, M. The vegan package. Community Ecol. Package 2007, 10, 631-637.

35. Wang, Y.I.; Naumann, U.; Wright, S.T.; Warton, D.I. mvabund-An R package for model-based analysis of multivariate abundance data. Methods Ecol. Evol. 2012, 3, 471-474. [CrossRef]

36. Wickham, H.; Wickham, M.H. The Ggplot Package. 2007. Available online: http://ftp.uni-bayreuth.de/ math/statlib/R/CRAN/doc/packages/ggplot.pdf (accessed on 1 November 2017).

37. Acha, P.N.; Szyfres, B. Zoonoses and Communicable Diseases Common to Man and Animals; Pan American Health Organization: Washington, DC, USA, 2001; Volume 3.

38. Paul, J. A checklist of bacteria associated with infection in humans. In Oxford Textbook of Medicine: Infection, 5th ed.; Oxford University Press: Oxford, UK, 2012.

39. Indra, A.; Lassnig, H.; Baliko, N.; Much, P.; Fiedler, A.; Huhulescu, S.; Allerberger, F. Clostridium difficile: A new zoonotic agent? Wien. Klin. Wochenschr. 2009, 121, 91. [CrossRef] [PubMed]

40. Elsden, S.R.; Hitchcock, M.W.S.; Marshall, R.A.; Phillipson, A.T. Volatile acids in the digesta of ruminants and other animals. J. Exp. Biol. 1946, 22, 191-202. [PubMed]

41. Patni, N.K.; Jui, P.Y. Volatile fatty acids in stored dairy-cattle slurry. Agric. Wastes 1985, 13, 159-178. [CrossRef]

42. Jami, E.; Israel, A.; Kotser, A.; Mizrahi, I. Exploring the bovine rumen bacterial community from birth to adulthood. ISME J. 2013, 7, 1069-1079. [CrossRef] [PubMed]

43. Clemente, J.C.; Ursell, L.K.; Parfrey, L.W.; Knight, R. The Impact of the Gut Microbiota on Human Health: An Integrative View. Cell 2012, 148, 1258-1270. [CrossRef] [PubMed]

44. Gillilland, M.G.; Young, V.B.; Huffnagle, G.B. Gastrointestinal microbial ecology with perspectives on health and disease. In Physiology of the Gastrointestinal Tract, 5th ed.; Elsevier: New York City, NY, USA, 2012; pp. 1119-1134.

45. Jami, E.; White, B.A.; Mizrahi, I. Potential Role of the Bovine Rumen Microbiome in Modulating Milk Composition and Feed Efficiency. PLoS ONE 2014, 9, e85423. [CrossRef] [PubMed]

46. Mizrahi, I. The Role of the Rumen Microbiota in Determining the Feed Efficiency of Dairy Cows. In Beneficial Microorganisms in Multicellular Life Forms; Springer: Berlin/Heidelberg, Germany, 2012; pp. 203-210, ISBN 978-3-642-21679-4.

47. Saraswati, S.; Sitaraman, R. Aging and the human gut microbiota-From correlation to causality. Front. Microbiol. 2015, 5. [CrossRef] [PubMed]

48. Vrieze, A.; Holleman, F.; Zoetendal, E.G.; de Vos, W.M.; Hoekstra, J.B.L.; Nieuwdorp, M. The environment within: How gut microbiota may influence metabolism and body composition. Diabetologia 2010, 53, 606-613. [CrossRef] [PubMed]

49. Aagnes, T.H.; Sørmo, W.; Mathiesen, S.D. Ruminal microbial digestion in free-living, in captive lichen-fed, and in starved reindeer (Rangifer tarandus tarandus) in winter. Appl. Environ. Microbiol. 1995, 61, 583-591. [PubMed]

50. Aivelo, T.; Laakkonen, J.; Jernvall, J. Population-and individual-level dynamics of the intestinal microbiota of a small primate. Appl. Environ. Microbiol. 2016, 82, 3537-3545. [CrossRef] [PubMed] 
51. Maurice, C.F.; Knowles, S.C.; Ladau, J.; Pollard, K.S.; Fenton, A.; Pedersen, A.B.; Turnbaugh, P.J. Marked seasonal variation in the wild mouse gut microbiota. ISME J. 2015, 9, 2423. [CrossRef] [PubMed]

52. Mathiesen, S.D.; Mackie, R.I.; Aschfalk, A.; Ringø, E.; Sundset, M.A.; Holzapfel, W.; Naughton, P. Microbial ecology of the gastrointestinal tract in reindeer-changes through season. Microb. Ecol. Grow. Anim. 2005, 73-100, 0444509267.

53. Mosbacher, J.B.; Michelsen, A.; Stelvig, M.; Hendrichsen, D.K.; Schmidt, N.M. Show Me Your Rump Hair and I Will Tell You What You Ate-The Dietary History of Muskoxen (Ovibos moschatus) Revealed by Sequential Stable Isotope Analysis of Guard Hairs. PLoS ONE 2016, 11, e0152874. [CrossRef] [PubMed]

54. Pedersen, S.H.; Tamstorf, M.P.; Abermann, J.; Westergaard-Nielsen, A.; Lund, M.; Skov, K.; Sigsgaard, C.; Mylius, M.R.; Hansen, B.U.; Liston, G.E. Spatiotemporal characteristics of seasonal snow cover in Northeast Greenland from in situ observations. Arct. Antarct. Alp. Res. 2016, 48, 653-671. [CrossRef]

55. Larsen, T.S.; Nilsson, N.Ö.; Blix, A.S. Seasonal changes in lipogenesis and lipolysis in isolated adipocytes from Svalbard and Norwegian reindeer. Acta Physiol. Scand. 1985, 123, 97-104. [CrossRef] [PubMed]

56. Crater, A.R.; Barboza, P.S. The rumen in winter: Cold shocks in naturally feeding muskoxen (Ovibos moschatus). J. Mammal. 2007, 88, 625-631. [CrossRef]

57. Crater, A.R.; Barboza, P.S.; Forster, R.J. Regulation of rumen fermentation during seasonal fluctuations in food intake of muskoxen. Comp. Biochem. Physiol. A. Mol. Integr. Physiol. 2007, 146, 233-241. [CrossRef] [PubMed]

58. Barboza, P.S.; Peltier, T.C.; Forster, R.J. Ruminal degradation increases with seasonal hyperphagia in muskoxen (Ovibos moschatus): A preliminary report. J. Anim. Feed Sci. 2004, 13, 711-714. [CrossRef]

59. Tajima, K.; Nonaka, I.; Higuchi, K.; Takusari, N.; Kurihara, M.; Takenaka, A.; Mitsumori, M.; Kajikawa, H.; Aminov, R.I. Influence of high temperature and humidity on rumen bacterial diversity in Holstein heifers. Anaerobe 2007, 13, 57-64. [CrossRef] [PubMed]

60. Dowd, S.E.; Callaway, T.R.; Wolcott, R.D.; Sun, Y.; McKeehan, T.; Hagevoort, R.G.; Edrington, T.S. Evaluation of the bacterial diversity in the feces of cattle using $16 \mathrm{~S}$ rDNA bacterial tag-encoded FLX amplicon pyrosequencing (bTEFAP). BMC Microbiol. 2008, 8, 125. [CrossRef] [PubMed]

61. Morrison, M.; Pope, P.B.; Denman, S.E.; McSweeney, C.S. Plant biomass degradation by gut microbiomes: More of the same or something new? Curr. Opin. Biotechnol. 2009, 20, 358-363. [CrossRef] [PubMed]

62. Steelman, S.M.; Chowdhary, B.P.; Dowd, S.; Suchodolski, J.; Janečka, J.E. Pyrosequencing of $16 S$ rRNA genes in fecal samples reveals high diversity of hindgut microflora in horses and potential links to chronic laminitis. BMC Vet. Res. 2012, 8, 231. [CrossRef] [PubMed]

63. Thomas, F.; Hehemann, J.-H.; Rebuffet, E.; Czjzek, M.; Michel, G. Environmental and gut bacteroidetes: The food connection. Front. Microbiol. 2011, 2, 93. [CrossRef] [PubMed]

64. Naas, A.E.; Mackenzie, A.K.; Mravec, J.; Schückel, J.; Willats, W.G.T.; Eijsink, V.G.H.; Pope, P.B. Do rumen Bacteroidetes utilize an alternative mechanism for cellulose degradation? MBio 2014, 5, e01401-e01414. [CrossRef] [PubMed]

65. Salyers, A.A.; Vercellotti, J.R.; West, S.E.; Wilkins, T.D. Fermentation of mucin and plant polysaccharides by strains of Bacteroides from the human colon. Appl. Environ. Microbiol. 1977, 33, 319-322. [PubMed]

66. Rincón, M.T.; McCrae, S.I.; Kirby, J.; Scott, K.P.; Flint, H.J. EndB, a multidomain family 44 cellulase from Ruminococcus flavefaciens 17 , binds to cellulose via a novel cellulose-binding module and to another R. flavefaciens protein via a dockerin domain. Appl. Environ. Microbiol. 2001, 67, 4426-4431. [CrossRef] [PubMed]

67. Ishaq, S.L.; Wright, A.-D. High-Throughput DNA Sequencing of the Ruminal Bacteria from Moose (Alces alces) in Vermont, Alaska, and Norway. Microb. Ecol. 2014, 68, 185-195. [CrossRef] [PubMed]

68. Vogtmann, E.; Chen, J.; Amir, A.; Shi, J.; Abnet, C.C.; Nelson, H.; Knight, R.; Chia, N.; Sinha, R. Comparison of collection methods for fecal samples in microbiome studies. Am. J. Epidemiol. 2017, 185, 115-123. [CrossRef] [PubMed]

69. Bernardet, J.; Bowman, J.P. Flavobacterium. Bergey's Man. Syst. Archaea Bact. 2015. [CrossRef]

70. Kämpfer, P.; Order, I. Sphingobacteriales ord. nov. Bergey's Man. Syst. Archaea Bact. 2011, 4, 330.

71. Alderisio, K.A.; DeLuca, N. Seasonal Enumeration of Fecal Coliform Bacteria from the Feces of Ring-Billed Gulls (Larus delawarensis) and Canada Geese (Branta canadensis). Appl. Environ. Microbiol. 1999, 65, 5628-5630. [PubMed] 
72. French, N.P.; Midwinter, A.; Holland, B.; Collins-Emerson, J.; Pattison, R.; Colles, F.; Carter, P. Molecular Epidemiology of Campylobacter jejuni Isolates from Wild-Bird Fecal Material in Children's Playgrounds. Appl. Environ. Microbiol. 2009, 75, 779-783. [CrossRef] [PubMed]

73. Tao, S.; Tian, P.; Luo, Y.; Tian, J.; Hua, C.; Geng, Y.; Cong, R.; Ni, Y.; Zhao, R. Microbiome-Metabolome Responses to a High-Grain Diet Associated with the Hind-Gut Health of Goats. Front. Microbiol. 2017, 8, 1764. [CrossRef] [PubMed]

74. Scott, K.P.; Gratz, S.W.; Sheridan, P.O.; Flint, H.J.; Duncan, S.H. The influence of diet on the gut microbiota. Pharmacol. Res. 2013, 69, 52-60. [CrossRef] [PubMed]

75. Mao, S.; Zhang, R.; Wang, D.; Zhu, W. The diversity of the fecal bacterial community and its relationship with the concentration of volatile fatty acids in the feces during subacute rumen acidosis in dairy cows. BMC Vet. Res. 2012, 8, 237. [CrossRef] [PubMed]

76. Heiman, M.L.; Greenway, F.L. A healthy gastrointestinal microbiome is dependent on dietary diversity. Mol. Metab. 2016, 5, 317-320. [CrossRef] [PubMed]

77. Blix, A.S.; Ness, J.; Lian, H. Experiences from 40 years of muskox (Ovibos moschatus) farming in Norway. Rangifer 2011, 31, 1-6. [CrossRef]

78. Norwegian Meteorological Institute (MET). Tromsø weather data: eKlima. Available online: http:// sharki.oslo.dnmi.no/portal/page?_pageid=73,39035,73_39049\&_dad=portal\&_schema=PORTAL (accessed on 1 December 2017).

79. Qaanaaq weather data: yr.no. Available online: https://www.yr.no/sted/Gr\%C3\%B8nland/Annet/ Qaanaaq/statistikk.html (accessed on 1 December 2017).

80. Groves, P. Intraspecific variation in mitochondrial DNA of muskoxen, based on control-region sequences. Can. J. Zool. 1997, 75, 568-575. [CrossRef]

81. Holm, L.-E.; Forchhammer, M.C.; Boomsma, J.J. Low genetic variation in muskoxen (Ovibos moschatus) from western Greenland using microsatellites. Mol. Ecol. 1999, 8, 675-679. [CrossRef] [PubMed]

82. Deehan, E.C.; Walter, J. The fiber gap and the disappearing gut microbiome: Implications for human nutrition. Trends Endocrinol. Metab. 2016, 27, 239-242. [CrossRef] [PubMed]

83. Sonnenburg, E.D.; Smits, S.A.; Tikhonov, M.; Higginbottom, S.K.; Wingreen, N.S.; Sonnenburg, J.L. Diet-induced extinctions in the gut microbiota compound over generations. Nature 2016, 529, 212. [CrossRef] [PubMed]

84. Tap, J.; Furet, J.-P.; Bensaada, M.; Philippe, C.; Roth, H.; Rabot, S.; Lakhdari, O.; Lombard, V.; Henrissat, B.; Corthier, G. Gut microbiota richness promotes its stability upon increased dietary fibre intake in healthy adults. Environ. Microbiol. 2015, 17, 4954-4964. [CrossRef] [PubMed]

85. Martínez, I.; Lattimer, J.M.; Hubach, K.L.; Case, J.A.; Yang, J.; Weber, C.G.; Louk, J.A.; Rose, D.J.; Kyureghian, G.; Peterson, D.A. Gut microbiome composition is linked to whole grain-induced immunological improvements. ISME J. 2013, 7, 269. [CrossRef] [PubMed]

86. Plaizier, J.C.; Li, S.; Danscher, A.M.; Derakshani, H.; Andersen, P.H.; Khafipour, E. Changes in Microbiota in Rumen Digesta and Feces Due to a Grain-Based Subacute Ruminal Acidosis (SARA) Challenge. Microb. Ecol. 2017, 74, 485-495. [CrossRef] [PubMed]

87. Abnous, K.; Brooks, S.P.; Kwan, J.; Matias, F.; Green-Johnson, J.; Selinger, L.B.; Thomas, M.; Kalmokoff, M. Diets enriched in oat bran or wheat bran temporally and differentially alter the composition of the fecal community of rats. J. Nutr. 2009, 139, 2024-2031. [CrossRef] [PubMed]

88. Middelbos, I.S.; Boler, B.M.V.; Qu, A.; White, B.A.; Swanson, K.S.; Fahey, G.C., Jr. Phylogenetic Characterization of Fecal Microbial Communities of Dogs Fed Diets with or without Supplemental Dietary Fiber Using 454 Pyrosequencing. PLoS ONE 2010, 5, e9768. [CrossRef] [PubMed]

89. Zhu, L.; Wu, Q.; Dai, J.; Zhang, S.; Wei, F. Evidence of cellulose metabolism by the giant panda gut microbiome. Proc. Natl. Acad. Sci. USA 2011, 108, 17714-17719. [CrossRef] [PubMed]

90. Kocherginskaya, S.A.; Aminov, R.I.; White, B.A. Analysis of the Rumen Bacterial Diversity under two Different Diet Conditions using Denaturing Gradient Gel Electrophoresis, Random Sequencing, and Statistical Ecology Approaches. Anaerobe 2001, 7, 119-134. [CrossRef]

91. Ley, R.E.; Turnbaugh, P.J.; Klein, S.; Gordon, J.I. Microbial ecology: Human gut microbes associated with obesity. Nature 2006, 444, 1022. [CrossRef] [PubMed] 
92. Turnbaugh, P.J.; Ridaura, V.K.; Faith, J.J.; Rey, F.E.; Knight, R.; Gordon, J.I. The Effect of Diet on the Human Gut Microbiome: A Metagenomic Analysis in Humanized Gnotobiotic Mice. Sci. Transl. Med. 2009, 1, 6 ra14. [CrossRef] [PubMed]

93. Turnbaugh, P.J.; Ley, R.E.; Mahowald, M.A.; Magrini, V.; Mardis, E.R.; Gordon, J.I. An obesity-associated gut microbiome with increased capacity for energy harvest. Nature 2006, 444, 1027. [CrossRef] [PubMed]

94. Godoy-Vitorino, F.; Goldfarb, K.C.; Karaoz, U.; Leal, S.; Garcia-Amado, M.A.; Hugenholtz, P.; Tringe, S.G.; Brodie, E.L.; Dominguez-Bello, M.G. Comparative analyses of foregut and hindgut bacterial communities in hoatzins and cows. ISME J. 2012, 6, 531. [CrossRef] [PubMed]

95. Callaway, T.R.; Dowd, S.E.; Edrington, T.S.; Anderson, R.C.; Krueger, N.; Bauer, N.; Kononoff, P.J.; Nisbet, D.J. Evaluation of bacterial diversity in the rumen and feces of cattle fed different levels of dried distillers grains plus solubles using bacterial tag-encoded FLX amplicon pyrosequencing. J. Anim. Sci. 2010, 88, 3977-3983. [CrossRef] [PubMed]

96. Dougal, K.; Harris, P.A.; Edwards, A.; Pachebat, J.A.; Blackmore, T.M.; Worgan, H.J.; Newbold, C.J. A comparison of the microbiome and the metabolome of different regions of the equine hindgut. FEMS Microbiol. Ecol. 2012, 82, 642-652. [CrossRef] [PubMed]

97. de Oliveira, M.N.V.; Jewell, K.A.; Freitas, F.S.; Benjamin, L.A.; Tótola, M.R.; Borges, A.C.; Moraes, C.A.; Suen, G. Characterizing the microbiota across the gastrointestinal tract of a Brazilian Nelore steer. Vet. Microbial. 2013, 164, 307-314. [CrossRef] [PubMed]

98. Davidson, R.K.; Amundsen, H.; Lie, N.O.; Luyckx, K.; Robertson, L.J.; Verocai, G.G.; Kutz, S.J.; Ytrehus, B. Sentinels in a climatic outpost: Endoparasites in the introduced muskox (Ovibos moschatus wardi) population of Dovrefjell, Norway. Int. J. Parasitol. Parasit. Wildl. 2014, 3, 154-160. [CrossRef] [PubMed]

99. Kutz, S.J.; Thompson, R.A.; Polley, L.; Kandola, K.; Nagy, J.; Wielinga, C.M.; Elkin, B.T. Giardia assemblage A: Human genotype in muskoxen in the Canadian Arctic. Parasit. Vectors 2008, 1, 32. [CrossRef] [PubMed]

100. Davidson, R.K.; Lavikainen, A.; Konyaev, S.; Schurer, J.; Miller, A.L.; Oksanen, A.; Skírnisson, K.; Jenkins, E. Echinococcus across the north: Current knowledge, future challenges. Food Waterborne Parasitol. 2016, 4, $39-53$. [CrossRef]

101. Schurer, J.; Shury, T.; Leighton, F.; Jenkins, E. Surveillance for Echinococcus canadensis genotypes in Canadian ungulates. Int. J. Parasitol. Parasit. Wildl. 2013, 2, 97-101. [CrossRef] [PubMed]

102. Woldehiwet, Z. Q fever (coxiellosis): Epidemiology and pathogenesis. Res. Vet. Sci. 2004, 77, 93-100. [CrossRef] [PubMed]

103. Billinis, C. Wildlife diseases that pose a risk to small ruminants and their farmers. Small Rumin. Res. 2013, 110, 67-70. [CrossRef]

104. Gates, C.C.; Wobeser, G.; Forbes, L.B. Rangiferine brucellosis in a muskox, Ovibos moschatus moschatus (Zimmermann). J. Wildl. Dis. 1984, 20, 233-234. [CrossRef] [PubMed]

105. Kutz, S.; Bollinger, T.; Branigan, M.; Checkley, S.; Davison, T.; Dumond, M.; Elkin, B.; Forde, T.; Hutchins, W.; Niptanatiak, A.; et al. Erysipelothrix rhusiopathiae associated with recent widespread muskox mortalities in the Canadian Arctic. Can. Vet. J. 2015, 56, 560-563. [PubMed]

106. Nymo, I.H.; Beckmen, K.; Godfroid, J. Anti-Brucella Antibodies in Moose (Alces alces gigas), Muskoxen (Ovibos moschatus), and Plains Bison (Bison bison bison) in Alaska, USA. J. Wildl. Dis. 2015, 52, 96-99. [CrossRef] [PubMed]

107. Hancock, D.; Besser, T.; Lejeune, J.; Davis, M.; Rice, D. The control of VTEC in the animal reservoir. Int. J. Food Microbiol. 2001, 66, 71-78. [CrossRef]

108. Wasteson, Y.; Arnemo, J.M.; Johansen, B.K.; Vold, L.; Mathiesen, S.D.; Olsen, M.A.; Wiig, Ø.; Derocher, A.E. Analysis of faecal samples from wild animals for verocytotoxin producing Escherichia coli and E. coli 0157. Vet. Rec. 1999, 144, 646-647. [CrossRef] [PubMed]

109. Wahlstrom, H.; Tysen, E.; Olsson Engvall, E.; Brandstrom, B.; Eriksson, E.; Morner, T.; Vagsholm, I. Survey of Campylobacter species, VTEC 0157 and Salmonella species in Swedish wildlife. Vet. Rec. 2003, 153, 74-80. [CrossRef] [PubMed]

110. Lukjancenko, O.; Wassenaar, T.M.; Ussery, D.W. Comparison of 61 Sequenced Escherichia coli Genomes. Microb. Ecol. 2010, 60, 708-720. [CrossRef] [PubMed]

111. Wasteson, Y. Zoonotic Escherichia coli. Acta Vet. Scand. 2002, 43, S79. [CrossRef] 
112. Forde, T.L.; Orsel, K.; Zadoks, R.N.; Biek, R.; Adams, L.G.; Checkley, S.L.; Davison, T.; De Buck, J.; Dumond, M.; Elkin, B.T.; et al. Bacterial Genomics Reveal the Complex Epidemiology of an Emerging Pathogen in Arctic and Boreal Ungulates. Front. Microbiol. 2016, 7, 1759. [CrossRef] [PubMed]

113. Mair, N.S. Yersiniosis in wildlife and its public health implications. J. Wildl. Dis. 1973, 9, 64-71. [CrossRef] [PubMed]

114. Nishi, J.S.; Shury, T.; Elkin, B.T. Wildlife reservoirs for bovine tuberculosis (Mycobacterium bovis) in Canada: Strategies for management and research. Vet. Microbiol. 2006, 112, 325-338. [CrossRef] [PubMed]

115. Handeland, K.; Tengs, T.; Kokotovic, B.; Vikøren, T.; Ayling, R.D.; Bergsjø, B.; Sigurðardóttir, Ó.G.; Bretten, T. Mycoplasma ovipneumoniae-A Primary Cause of Severe Pneumonia Epizootics in the Norwegian Muskox (Ovibos moschatus) Population. PLoS ONE 2014, 9, e106116. [CrossRef] [PubMed]

116. Ytrehus, B.; Bretten, T.; Bergsjø, B.; Isaksen, K. Fatal pneumonia epizootic in musk ox (Ovibos moschatus) in a period of extraordinary weather conditions. EcoHealth 2008, 5, 213-223. [CrossRef] [PubMed]

117. Båverud, V.; Gustafsson, A.; Franklin, A.; Aspán, A.; Gunnarsson, A. Clostridium difficile: Prevalence in horses and environment, and antimicrobial susceptibility. Equine Vet. J. 2003, 35, 465-471. [CrossRef] [PubMed]

118. Bredy, J.P.; Botzler, R.G. The effects of six environmental variables on Pasteurella multocida populations in water. J. Wildl. Dis. 1989, 25, 232-239. [CrossRef] [PubMed]

119. Brooke, C.J.; Riley, T.V. Erysipelothrix rhusiopathiae: Bacteriology, epidemiology and clinical manifestations of an occupational pathogen. J. Med. Microbiol. 1999, 48, 789-799. [CrossRef] [PubMed]

120. Jensen, G.B.; Hansen, B.M.; Eilenberg, J.; Mahillon, J. The hidden lifestyles of Bacillus cereus and relatives. Environ. Microbiol. 2003, 5, 631-640. [CrossRef] [PubMed]

121. Whittington, R.J.; Marshall, D.J.; Nicholls, P.J.; Marsh, I.B.; Reddacliff, L.A. Survival and dormancy of Mycobacterium avium subsp. paratuberculosis in the environment. Appl. Environ. Microbiol. 2004, 70, 2989-3004. [CrossRef] [PubMed]

122. Seidel, K.B.; Rowell, J.E. Canadian Muskoxen in Central Europe-A Zoo Veterinary Review. Rangifer 1996, 16, 79-85. [CrossRef]

123. Mikko, S.; Røed, K.; Schmutz, S.; Andersson, L. Monomorphism and polymorphism at Mhc DRB loci in domestic and wild ruminants. Immunol. Rev. 1999, 167, 169-178. [CrossRef] [PubMed]

124. Barton, M.D.; Hughes, K.L. Is Rhodococcus equi a soil organism? J. Reprod. Fertil. Suppl. 1982, 32, $481-489$. [PubMed] 